\title{
PENGARUH PEMBELAJARAN JARAK JAUH ( PJJ ) PADA MATA PELAJARAN PENJAS TERHADAP HASIL BELAJAR PSIKOMOTOR SISWA KELAS 1A DI SDIT ADZKIA2 KOTA SUKABUMI TAHUN AJARAN 2020/2021
}

\author{
Isep Riki Rinaldi ${ }^{1}$ \\ Universitas Muhammadiyah Sukabumi ${ }^{1}$ \\ Isepriki005@gmail.com
}

\begin{abstract}
ABSTRAK
Penelitian ini bertujuan untuk mengetahui pengaruh pembelajaran jarak jauh ( pjj ) pada mata pelajaran penjas terhadap hasil belajar siswa kelas 1A SDIT Adzkia2 Kota Sukabumi. Penelitian ini menggunakan metode kuantitatif (Pretest-Posttest Control Grup Design). Populasi penelitian ini merupakan di ambil dari siswa kelas 1A SDIT Adzkia2 Kota Sukabumi yang berjumlah 25 orang sampel yang diambil 25 orang. Berdasarkan hasil perhitungan menggunakan teknik analisis uji-T. Di peroleh hasil T hitung lebih besar dari $\mathrm{T}$ tabel yaitu $\mathrm{T}$ hitung $(6,4378)$ dan $\mathrm{T}$ tabel $(2,06389)$. berdasarkan taraf signifikansi 0.05 maka $\mathrm{H} \alpha$ di terima artinya ada pengaruh metode video pembelajaran yang dibuat dan dipraktekan langsung oleh guru SDIT Adzkia2 terhadap hasil belajar psikomotor siswa kelas 1A di SDIT Adzkia2 Kota Sukabumi.
\end{abstract}

Kata Kunci: pembelajaran jarak jauh; metode; video pembelajaran.

\begin{abstract}
This study aims to determine the effect of distance learning (pjj) on Physical Education subjects on the learning outcomes of class 1A students at SDIT Adzkia2 Sukabumi City. This research uses quantitative methods (PretestPosttest Control Group Design). The population of this research is taken from the students of class $1 A$ SDIT Adzkia2 Sukabumi City, amounting to 25 people, the sample is taken 25 people. Based on the results of calculations using the T-test analysis technique. The results obtained are $T$ count greater than $T$ table, namely $T$ count (6.4378) and T table (2.06389). based on the significance level of 0.05, Ho is accepted, meaning that there is an effect of the learning video method made and practiced directly by SDIT Adzkia2 teachers on the psychomotor learning outcomes of class 1A students at SDIT Adzkia2 Sukabumi City.
\end{abstract}

Keywords: distance learning; video; learning method.

Dipublikasikan Oleh :

UPT Publikasi dan Pengelolaan Jurnal

Universitas Islam Kalimantan Muhammad Arsyad Al-Banjari Banjarmasin 


\section{PENDAHULUAN}

Pendidikan Jasmani adalah bentuk pendidikan yang memberikan perhatian pada pengajaran pengetahuan, sikap dan keterampilan gerak manusia. Pendidikan Jasmani mempunyai keunikan dibandingkan dengan pendidikan yang lain, yaitu yang memberikan kesempatan untuk mengembangkan karakter dan sifat sosial yang lebih besar untuk mewujudkan dalam praktik pengajaran.

Pendidikan adalah proses pembelajaran kemampuan, pengetahuan, dan keterampilan yang dilihat dari kebiasaan seseorang, pendidikan merupakan usaha sadar secara sistematis dan dinamis bertujuan mewujudkan pembelajaran serta meningkatkan potensi dari setiap peserta didik. Kemampuan serta keahlian diri yang terus berkembang berkala secara individual proses tahapan dalam perubahan sikap etika prilaku seseorang atau kelompok dalam meningkatkan pola pikir manusia melalui pengajaran.

Pembelajaran adalah suatu proses upaya dilakukan oleh pendidik kepada siswa untuk menyampaikan atau memberikan pengetahuan, aktivitas pembelajaran untuk menciptakan sistem lingkungan dengan metodepembelajaran sehingga dapat belajar dengan efektif, aktif, dan efesiensi.Berdasarkan UU Nomor 20 Tahun 2003 tentang Sistem Pendidikan Nasional, disebutkan bahwa pembelajaran adalah proses interaksi siswa dengan pendidik dan sumber belajar pada suatu lingkungan belajar.

Proses pembelajaran PJOK disekolah melalui aspek permainan dan olahraga, aktivitas pengembangan jasmani pendidikan luar kelas yang menuntut siswa untuk bisa dan tahu tidak untuk ahli serta sebatas pencapaian tujuan belajar mengajar. Untuk mencapai tujuan dalam pelaksanaan pembelajaran maka PJOK menjadi salah satu faktor yang dapat mempengaruhi motivasi siswa.

Dunia pendidikan menghadapi permasalahan yang cukup kompleks di masa pandemi covid-19. Serangan virus yang hingga kini belum ditemukan vaksinnya tersebut berdampak pada penyelenggaraan pembelajaran pada semua jenjang pendidikan. Jenjang perguruan tinggi dan sebagian sekolah menengah yang sudah terbiasa menerapkan pembelajaran online tidak mengalami banyak kendala dalam menghadapi pandemi covid-19, tidak demikian dengan jenjang pendidikan dasar (sekolah dasar) yang bahkan membawa perangkat komunikasi (handphone) ke sekolah atau ke ruang kelas dilarang.

Hal ini sangat berpengaruh terhadap proses pembelajaran di sekolah, Berdasarkan (Kementerian Pendidikan dan Kebudayaan, 2020) Nomor 4 Tahun 2020 tentang Pelaksanaan Kebijakan Pendidikan Dalam Masa Darurat Penyebaran Corona Virus Disease 2019 (Covid-19) melalui Surat Edaran Sekretaris Jenderal No.15 Tahun 2020 tentang Pedoman Pelaksanaan Belajar dari Rumah selama Darurat Bencana (Covid-19) Tujuan diberlakukannya belajar dari rumah yaitu untuk (1) Memastikan pemenuhan hak anak untuk mendapatkan layanan pendidikan selama darurat COVID-19 (2) Melindungi warga satuan pendidikan dari dampak buruk COVID-19 (3) Mencegah penyebaran dan penularan COVID-19 di satuan pendidikan (4) Memastikan pemenuhan dukungan psikososial bagi pendidik, peserta didik dan orang tua/wali. Setelah diterbitkan surat edaran tersebut maka proses pembelajaran mulai dari tingkat Perguruan Tinggi sampai PAUD harus dilaksanakan dari rumah. Tidak terkecuali untuk jenjang Sekolah Dasar/ Madrasah Ibtidaiyah juga melakukan proses pembelajaran dalam jaringan (daring) dari rumah.

Pembelajaran adalah proses interaksi peserta didik dengan pendidik dan sumber belajar pada suatu lingkungan belajar (UU No. 20/2003, Bab I Pasal Ayat 20) dalam (PENDIDIKAN, 2003). Pada masa pandemi (covid-19) ini, perlu ada pendalaman pemahaman mengenai materi kesehatan yang dapat membantu antisipasi penularan virus kepada pendidik, peserta didik dan orang tua. Materi kesehatan tersebut bisa didapat melalui pembelajaran penjas, diantaranya tentang pola hidup sehat, jaga kebersihan dan kebugaran jasmani.

Hal ini sejalan dengan (Permendiknas, 2006) bahwa untuk membantu siswa memantapkan kebugaran jasmani dan kesehatan melalui pengenalan dan penanaman sikap positif serta membangkitkan motivasi dalam belajar untuk meningkatkan kemampuan gerak dasar sebagai aktivitas jasmani antara lain :

(1) Terbentuknya sikap dan perilaku seperti : disiplin, kejujuran,, kerja sama mengikuti peraturan dan ketentuan yang berlaku ;

(2) Mempunyai kemampuan untuk menjelaskan tentang manfaat pendidikan jasmani dan kesehatan serta mempunyai kemampuan, penampilan, keterampilan gerak benar dan efisien:

(3) Meningkatkan kebugaran jasmani dan kesehatan daya tahan tubuh terhadap penyakit. Untuk memenuhi keperluan berjalanya proses pembelajaran penjas secara dalam jaringan (daring), maka perlu adanya sinergi antara pendidik, peserta didik dan wali murid guna mempersiapkan sumber belajar dan sarana prasarana penunjang untuk melakukan pembelajaran penjas secara dalam jaringan (daring).

\section{METODE}

Penelitian ini merupakan penelitian Ex Post Facto karena variabel bebas dalam penelitian ini tidak dikendalikan atau diperlakukan khusus melainkan hanya mengungkap fakta berdasarkan pengukuran gejala yang telah ada pada diri responden sebelum penelitian ini dilaksanakan. Hal ini sesuai dengan pendapat

Dipublikasikan Oleh :

UPT Publikasi dan Pengelolaan Jurnal

Universitas Islam Kalimantan Muhammad Arsyad Al-Banjari Banjarmasin 
Sugiyono yang mengemukakan bahwa penelitian Ex Post Facto adalah suatu penelitian yang dilakukan untuk meneliti peristiwa yang telah terjadi dan kemudian merunut ke belakang untuk mengetahui faktor-faktor yang dapat menyebabkan timbulnya kejadian tersebut. Penelitian ini menggunakan logika dasar yaitu jika x maka y. Dalam penelitian tidak ada manipulasi langsung terhadap variabel independen (Sugiyono, dalam Aditya Nugroho 2013:25).

Desain penelitian adalah rancangan tentang cara menyimpulkan dan menganalisis data agar dapat dilaksanakan secara ekonomis dan sesuai dengan tujuan penelitian. Pada penelitian ini peneliti menggunakan desain eksperimen penelitian yaitu dengan menggunakan Pretest - Posttest Control Grup Design, seperti yang di jelaskan Sugiyono dalam muslihin (2020: 29) adalah "Dalam desain ini tedapat dua kelompok yang dipilih secara random kemudian diberi pretest untuk mengetahui keadaan awal adakah perbedaan anatara kelompok eksperiment dan kelompok kontrol". Berdasarkan desain penelitian diatas di atas, penelitian ini dilakukan pada dua metode pembelajaran jarak jauh yaitu metode satu menggunakan video pembelajaran yang dibuat dan di praktekan oleh guru dari luar sekolah SDIT Adzkia2 Kota Sukabumi.

\section{Populasi}

Menurut Sugiyono dalam Aditya Nugroho (2013: 30) populasi adalah wilayah generalisasi yang terdiri atas obyek/subyek yang mempunyai kualitas dan karakteristik tertentu yang ditetapkan oleh penelitian untuk dipelajari dan kemudian ditarik kesimpulan. Populasi dapat diambil sejumlah data yang diperlukan untuk memecahkan masalah yang diteliti.

Dalam penelitian kuantitatif ini dapat dikatakan populasi dan sampel namun dalam penelitian pengaruh di namakan subjek penelitian. Jumlah populasi yang peneliti gunakan adalah 25 siswa dari kelas 1A yang mengikuti proses belajar via sistem daring mata pelajaran pendidikan jasmani di SDIT Adzkia2 Kota Sukabumi Tahun Pelajaran 2020/2021.

2. Sample.

Menurut Sugiyono dalam Gartika(2016: 81) sampel adalah bagian dari jumlah dan karakteristik yang dimiliki oleh populasi tersebut. Menurut Arikunto (2010: 174) sampel adalah sebagian atau wakil populasi yang diteliti. Jumlah populasi yaitu 25 siswa dijadikan sampel sehingga penelitian populasi ini menggunakan total sampling.

Instrument penelitian yang digunakan oleh peneliti dalam penelitian ini adalah pret-test. Post-test merupakan suatu teknik atau cara pengumpulan data secara tidak langsung (peneliti tidak langsung bertanya-jawab dengan responden). Instrumen atau alat pengumpulan datanya juga harus mempraktekan kembali video pembel ajaran yang sudah guru berikan.

Tabel 1. Penilaian Hasil Belajar (Psikomotor)

\begin{tabular}{|c|c|c|c|c|c|c|c|c|c|c|c|c|c|c|c|}
\hline \multicolumn{12}{|c|}{ Aspek yang dinilai } & \multirow{2}{*}{ Skor } & \multirow[t]{3}{*}{ Nilai } & \multirow{2}{*}{\multicolumn{2}{|c|}{ Ket. }} \\
\hline \multicolumn{4}{|c|}{ Sikap Awal } & \multicolumn{4}{|c|}{ Gerakan } & \multicolumn{4}{|c|}{ Sikap Akhir } & & & & \\
\hline 4 & 3 & 2 & 1 & 4 & 3 & 2 & 1 & 4 & 3 & 2 & 1 & & & $\mathbf{T}$ & BT \\
\hline & & & & & & & & & & & & & & & \\
\hline & & & & & & & & & & & & & & & \\
\hline & & & & & & & & & & & & & & & \\
\hline & & & & & & & & & & & & & & & \\
\hline & & & & & & & & & & & & & & & \\
\hline & & & & & & & & & & & & & & & \\
\hline
\end{tabular}

\section{Deskriptif pengamatan terhadap aktifitas siswa}

\section{Sikap awal}
a. Badan tegak
b. Pandangan lurus ke depan
c. Tangan berada di samping badan,
d. Tangan diayunkan.

Dipublikasikan Oleh : 


\section{Gerakan Pelaksanaan}

a) Lengan dan bahu tidak harus diangkat terlalu banyak selama bergerak maju dan tubuh tegak sedikit condong sekitar 5 derajat ke depan

b) Tumpuan kaki tidak terputus kontak dengan bumi, misalnya kaki depan harus menginjak tanah sebelum kaki belakang

c) Pinggul dijaga tetap rendah dan di bawah selama berjalan dan tidak ada gerakan ke samping yang berlebihan

d) Lutut kaki tumpuan harus tetap lurus pada waktu fase menumpu dan kaki bergerak sepanjang garis lurus dan tidak memotong bayangan jalan

\section{Sikap Akhir}

a) Saat masuk garis finis tidak melompat

b) Saat menyentuh garis finis badan condong ke depan

c) Setelah masuk garis finis tidak langsung berhenti

d) Pandangan kearah garis finis.

Kriteria Penilaian:

Skor 4 : Jika siswa melaksanakan empat deskriptif.

Skor 3 : Jika siswa melaksanakan tiga deskriptif.

Skor 2 : Jika siswa melaksanakan dua deskriptif.

Skor 1 : Jika siswa melaksanakan satu deskriptif.

Skor 0 : Jika siswa tidak melaksakan

Setelah data terkumpul,maka langkah selanjutnya adalah menganalisa data tersebut. Teknik analisis data untuk menganalisis data eksperimen dengan model pretest posttest design adalah dengan menggunakan uji-t (t-test). Menurut Suharsimi dalam krisna girindra putra (2005 : 42) rumus uji-t untuk model pretest posttest design adalah sebagai berikut:Dengan Keterangan :

Langkah-langkah uji dua sampel berpasangan ( paired t-test )

1. Susun hipotesis yang akan diuji dan sesudah )

$\mathrm{H} 0:(\mu 1-\mu 2)=0$ atau $\mu 1=\mu 2$ ( tidak terdapat perbedaan yang signifikan antara hasil belajar sebelum sesudah )

H1 : $(\mu 1-\mu 2) \neq 0$ atau $\mu 1 \neq \mu 2$ ( terdapat perbedaan yang signifikan hasil belajar sebelum dan

2. Tentukan nilai alpha

Karena tingkat kepercayaan 95\% maka alpha 5\% $=0,05$

3. Tentukan statistic uji.

Uji yang digunakan adalah uji t dengan menggunakan tiga cara yaitu t-hitung sebagai berikut:

1. $\mathrm{t}$ hitung $=\frac{B}{S_{B}}$

2. $\quad$ hitung $=\frac{X 1-X 2}{\sqrt{\frac{s 1^{2}}{n 1}+\frac{s 2^{2}}{n 2}-2 r\left(\frac{s 1}{\sqrt{n 1}}\right)\left(\frac{s 2}{\sqrt{n 2}}\right)}}$

3. Dengan menggunakan rumus excel

4. Tentukan nilai aturan penolakan $\mathrm{HO}$

Dipublikasikan Oleh :

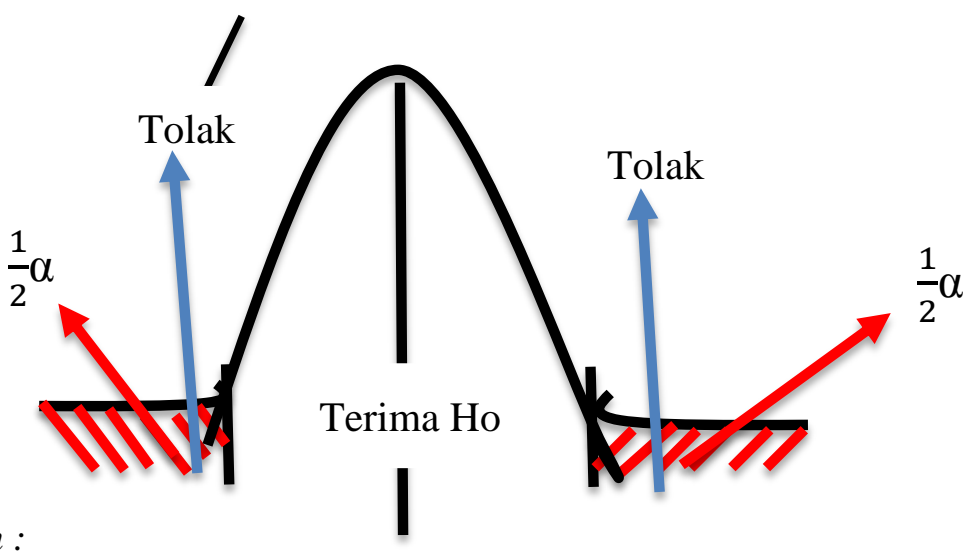

UPT Publikasi dan Pengelolaan Jurnal

Universitas Islam Kalimantan Muhammad Arsyad Al-Banjari Banjarmasin 


$$
-t \frac{1}{2} \alpha \quad t \frac{1}{2} \alpha
$$

H0 ditolak jika $\mid$ t-hitung $\mid>$ t-tabel atau p-value $<$ alpha

\section{HASIL DAN PEMBAHASAN}

Deskripsi hasil analisis data tes awal dan tes akhir video pembelajaran yang di buat dan di praktekan oleh guru SDIT Adzkia2 Kota Sukabumi yang dilakukan pada pada siswa kelas 1A SDIT Adzkia2 Kota Sukabumi disajikan dalam bentuk tabel.

1. Penjelasan data penelitian

Setelah melakukan uji tes awal dan uji tes akhir serta mengolah data, maka peneliti mendeskripsikan hasil data dari tes tersebut dalam bentuk tabel.

Tabel 2. Analisis Hasil data tes Pretes dan Postest PJJ Guru

\begin{tabular}{|l|l|l|l|l|l|}
\hline PJJ GURU N & N & Jumlah & Rata-rata & SD & Var \\
\hline $\begin{array}{l}\text { PJJ Guru dari Luar } \\
\text { (pretest) }\end{array}$ & \multirow{2}{*}{25} & $-7,46 \mathrm{E}-14$ & 53,88 & 452,94 & 452,9433 \\
\cline { 1 - 5 } $\begin{array}{l}\text { PJJ Guru dari SDIT } \\
\text { Adzkia2 (postest) }\end{array}$ & & 9606,560 & 79,64 & 139,24 & 139,24 \\
\hline
\end{tabular}

Berdasarkan tabel 4.1 dapat diketahui jumlah nilai dari tes awal hasil video pembelajaran psikomotor dari jumlah $\mathrm{N} 25$, serta rata-ratanya 53,88 dan SD 452,94. Jumlah nilai dari tes akhir video pembelajaran psikomotor dari jumlah N 25 serta rata-ratanya 79,64 dan SD 139,24 .

2. Analisis Data Pengujian Hipotesis dengan uji t (t-test)

selanjutnya dilakukan uji hipotesis dengan pendekatan uji t. analisis data dilakukan dengan uji t pada data pretest dan posttest peningkatan hasil belajar psikomotor siswa kelas 1A SDIT Adzkia2 Kota Sukabumi. Didalamnya akan menguji hipotesis.

Hasil dari analisis data yang sudah di olah dari hasil pretest dan posttest di tentukan dari uji t maka terdapat kesimpulan bahwa Ho di tolak dan Ha diterima maka bisa dijelaskan $\mathrm{H} \alpha$ : terdapat pengaruh yang signifikan antara metode pembelajaran jarak jauh terhadap hasil belajar psikomotor siswa kelas 1A SDIT Adzkia2 Kota Sukabumi, dalam hasil analisis juga bahwa antara metode PJJ dari guru luar sekolah dan metode PJJ dari guru langsung SDIT Adzkia2 terdapat perbandingan bisa di lihat dari hasil uji t di atas Ho di tolak dan Ha di terima. Untuk menerima atau menolak $\mathrm{H} \alpha$ harus membandingkan harga Thitung dengan Ttabel. Kriterianya yaitu menerima $\mathrm{H} \alpha$ apabila Thitung $\geq$ Ttabel , H $\alpha$ di tolak apabila Thitung $\leq$ Ttabel pada taraf signifikan 0.05 , untuk lebih jelasbya bisa dilihat dalam tabel berikut:

Tabel 3. Pengujian nilai dari hasil peningkatan hasil belajar psikomotor

\begin{tabular}{|l|l|l|}
\hline Thitung & Ttabel & Ket \\
\hline 6,4378 & 1,71387 & Ada perbandingan \\
\hline
\end{tabular}

Hasil dari penghitungan dengan pendekatan uji t yaitu diperoleh 6,4378. Hasil peritungan ini ternyata lebih kecil dari nilai Ttabel yang berjumlah 1,71387 , dengan demikian hipotesis $(\mathrm{H} \alpha)$ diterima, yang artinya: Ho- ada pengaruh yang signifikan antara ada pengaruh yang signifikan antara metode video pembelajaran jarak jauh yang dibuat oleh guru dari luar sekoah dengan metode pembelajaran jarak jauh yang dibuat dan dipraktekan langsung oleh guru SDIT Adzkia2 Kota Sukabumi. Video pembelajaran yang di buat oleh guru sdit adzkia2 Kota Sukabumi.

Video pembelajaran ini dilakukan di SDIT Adzkia2 Kota Sukabumi. Penerapan video pembelajaran ini dilakukan selama 1 kali dalam 1 minggu merujuk dari jadwal pembelajaran penjas di SDIT Adzkia2 Kota Sukabumi yang dilaksanakan selama 17 kali pertemuan.

Hasil dari penelitian ini menunjukan mengapa pembelajaran yang dibuat dan di praktekan oleh guru SDIT Adzkia2 Kota Sukabumi ada pengaruh yang signifikan terhadap hasil belajar psikomotor siswa kelas 1A SDIT Adzkia2 Kota Sukabumi?

Dipublikasikan Oleh : 
Berdasarkan hasil dari pengamatan serta evaluasi setiap pembelajaran peneliti membuat catatan-catatan perkembangan siswa pada saat pembelajaran dan pengirimkan tugas video kepada guru SDIT Adzkia2 Kota Sukabumi,mereka antusias mengirimkan tugas video praktek siswa kepada guru di SDIT Adzkia2 Kota Sukabumi,hal ini terlihat dari antusiasnya siswa yang mengikuti arahan-arahan atau tugas untuk mempraktekan kembali apa yang guru praktekan dalam video pembelajarannya.

Merujuk dari pertanyaan diatas, mengapa video pembelajaran yang dibuat oleh guru SDIT Adzkia2 Kota Sukabumi ada pengaruh terhadap hasil belajar psikomotor siswa kelas 1A SDIT Adzkia2 Kota Sukabumi,karena siswa lebih semangat dan antusias untuk melihat gurunya sendiri yang mempraktekan video pembelajaran penjas dari pada video pembelajaran yang di buat oleh orang lain.

Disinilah mengapa video pembelajaran yang dibuat dan dipraktekan oleh guru SDIT Adzkia2 Kota Sukabumi berpengaruh terhadap hasil belajar psikotor siswa kelas 1A SDIT Adzkia2 Kota Sukabumi

Setelah pengambilan tes akhir atau ujian akhir semester ( UAS ) dan evaluasi pengamatan pada setiap pembelajaran selama 5 kali pertemuan, peneliti membuat catatan-catatan perkembangan siswa saat video pembelajaran yang dibuat dan dipraktekan oleh guru di berikan, dilakukan uji hipotesis dengan cara pendekatan uji t. uji t dilakukan pada data tes awal ujian tengah smester ( UTS ) dan tes akhir ujian akhir smester ( UAS ) peningkatan hasil belajar psikomotor siswa SDIT Adzkia2 Kota Sukabumi, hasilnya ada pengaruh yang signifikan dari video pembelajaran yang dibuat .

Sistem pembelajaran jarak jauh di SDIT Adzkia2 Kota Sukabumi menggunakan media pembelajaran melalui video.Guru di SDIT Adzkia2 Kota Sukabumi melakukan pembelajaran jarak jauh dengan mengirimkan video pembelajaran di grup whatshap kelas 1A SDIT Adzkia2 Kota Sukabumi. Kemudian guru menginstruksikan siswa untuk menyimak video yang telah di berikan oleh guru SDIT Adzkia2 Kota Sukabumi. Setelah siswa menyimak video yang telah diberikan oleh guru,siswa diberi tugas untuk mempraktekan kembali gerakan yang ada dalam video yang telah diberikan oleh guru.

Sebelum ulangan tengah semester ( UTS ) siswa diberikan video pembelajaran yang dibuat dan dipraktikan oleh guru dari luar SDIT Adzkia2 Kota Sukabumi, dan setelah ulangan tengah semester ( UTS ) metode pembelajaran jarak jauh melalui video siswa diberikan video pembelajaran yang di buat dan dipraktekan oleh guru SDIT Adzkia2 Kota Sukabumi.

\section{PENUTUP}

Berdasarkan hasil analisis data dan pembahasan maka dapat diambil sebagai simpulan penelitian bahwa ada pengaruh video pembelajaran yang dibuat dan dipraktekan oleh guru SDIT Adzkia2 Kota Sukabumi terhadap hasil belajar psikomotor siswa kelas 1A SDIT Adzkia2 Kota Sukabumi,karena dalam penelitian ini siswa SDIT Adzkia2 Kota Sukabumi lebih antusias dan semangat untuk membuka dan melihat video yang dibuat dan dpraktekan oleh guru SDIT Adzkia2 Kota Sukabumi. Seperti yang sudah dijelaskan di atas bahwa video pembelajaran yang dibuat dan dpraktekan oleh guru SDIT Adzkia2 Kota Sukabumi yang diberikan terdapat pengaruh yang signifikan terhadap hasil belajar psikomotor siswa kelas 1A SDIT Adzkia2 Kota Sukabumi tahun ajaran 2020/2021.

\section{REFERENSI}

Ahmad Jayud dan Edi Irwanto (2020) Model pembelajaran daring sebagai alternatif proses kegiatan belajar pendidikan jasmani di tengah pandemic covid-19: UNIVERSITAS PGRI BAYUWANGI.

Aditya Nugroho (2013) Pengaruh motivasi dan minat terhadap prestasi siswa pada mata diklat keselamatan dan kesehatan kerja di Smk Negeri 1 Bayuwangi: Universitas Negeri Yogyakarta.

Edi Susanto (2009) Pengaruh pembelajaran online terhadap prestasi belajar kimia di tinjau dari kemampuan awal siswa: Universitas Sebelas Maret Surakarta.

Gartika Sabri Ningtyas ( 2020) Survei motivasi belajar siswa mata pelajaran pendidikan jasmani olahraga dan kesehatan via system pembelajaran daring kelas X Smk Muhammadiyah 1 Sukabumi: Universitas Muhammadiyah Sukabumi.

Juliansyah noor ( 2011 ) Metodologi penelitian, Prenadamedia group, Jakarta.

Dipublikasikan Oleh :

UPT Publikasi dan Pengelolaan Jurnal

Universitas Islam Kalimantan Muhammad Arsyad Al-Banjari Banjarmasin 
Izmi Ulfayani (2010) Evektivitas penerapan model pembelajaran berdasarkan masalah terhadap peningkatan hasil belajar siswa pada pokok bahasan virus kelas X Smk Makasar Mulya: Universitas Islam Negeri Alauddin Makasar.

Ngadino (2013) Upaya peningkatan hasil ketepatan lemparan bola ke ring basket dengan metode kombinasi permainan target pada siswa kelas V SD Negeri Deresan: Universitas Negeri Yogyakarta.

Septiyana Dwi Rahmawati (2009) Kendala Pelaksanaan jarak jauh melalui internet pada mahasiswa pjj S1 PGSD: Universitas Negeri Semarang.

Dipublikasikan Oleh : 